\title{
Creep and residual properties of cracked macro-synthetic fibre reinforced concretes
}

\section{Pedro Serna Ros}

Professor, ICITECH, Institute of Concrete Science and Technology, Universitat Politècnica de València, Valencia, Spain

\section{José R. Martí-Vargas}

Professor, ICITECH, Institute of Concrete Science and Technology, Universitat Politècnica de València, Valencia, Spain

\section{María E. Bossio}

PhD student, CONICET, National Council of Scientific and Technological Research, Civil Engineering Department, National University of La Plata, Buenos Aires, Argentina

\author{
Raul Zerbino \\ Professor, CONICET, National Council of Scientific and Technological \\ Research. Civil Engineering Department, National University of La Plata, \\ Buenos Aires, Argentina
}

This study analysed the creep behaviour of five concretes incorporating $\mathbf{0 . 5 \%}$ by volume of four macro-synthetic fibres (MSFs) and one steel fibre. After $28 \mathrm{~d}$ moist curing, prisms were pre-loaded up to a crack opening of $0.5 \mathrm{~mm}$ and held for $90 \mathrm{~d}$ in three different environments - ambient laboratory air, seawater at $45^{\circ} \mathrm{C}$ and air flow at $45^{\circ} \mathrm{C}$. Sustained loads were then applied on three specimens from each group while the other prisms remained unloaded. The remaining residual capacity was evaluated by bending tests. It was concluded that the residual capacity of cracked MSF concretes is not affected by long-term loading.

\section{Notation \\ $f_{\mathrm{L}} \quad$ first-peak flexural strength \\ $f_{\mathrm{R} 1} \quad$ residual flexural strength at $0.5 \mathrm{~mm}$ \\ $f_{\mathrm{R} 3} \quad$ residual flexural strength at $2.5 \mathrm{~mm}$ \\ $w_{\text {cd }} \quad$ deferred crack opening at the time prior to unloading \\ $w_{\text {ci }} \quad$ instantaneous crack opening in the loading process during the creep phase \\ $w_{\text {cd }}^{\mathrm{j}} \quad$ deferred crack opening at time $j$ \\ $w_{\mathrm{ci}}^{\mathrm{o}} \quad$ instantaneous crack opening \\ $w_{\mathrm{p}} \quad$ maximum crack opening during pre-cracking \\ $w_{\text {pr }} \quad$ residual crack opening after unloading \\ $\varphi_{\mathrm{w}}^{\mathrm{o} j} \quad$ creep coefficient at time $j$}

\section{Introduction}

The incorporation of fibres into a concrete matrix controls the cracking processes and thus introduces significant improvements in toughness and durability. Fibre reinforced concrete (FRC) is a high-performance material that is recommended in many applications in order to improve the service life of structures by means of its crack control capacity (Aslani and Nejadi, 2013; Ganesan et al., 2014). When incorporated into concrete, fibres will mainly start to carry stress after microcracking of the matrix begins (Mazhar et al., 2013). In the post-cracking stage, the fibres bridge the cracks and control their propagation by means of the chemical and physical bond or anchorage that develops during the fibre pull-out or slip processes (de Montaignac et al., 2013).
It has been observed that fibres significantly enhance the static mechanical properties of concrete as well as improving its post-peak response and ductile behaviour (Noushini et al., 2014). The concept of residual stress is now widely accepted as a means of mechanical characterisation of FRC. The residual stress represents the FRC's post-peak capacity for different crack mouth openings. EN 14651 (BSI, 2005) considers four residual stresses for crack opening displacements of $0 \cdot 5$ $3.5 \mathrm{~mm}$, and ASTM C1609 (ASTM, 2007) also defines two residual strengths.

Many studies on the behaviour of FRC have been conducted to determine the effects of different types of fibres on the mechanical properties of concrete (Naghibdehi et al., 2014). Most experiences that contributed to the formulation of the FRC chapters in the fib Model Code for Concrete Structures 2010 (fib, 2013) (MC2010 hereafter) were obtained from concretes reinforced with steel fibres. Although residual stress parameters are applied in structural design, knowledge of the long-term behaviour of FRC in cracked conditions is limited. MC2010 indicates that the long-term performance of FRC could be affected by creep. In general terms, steel fibre filaments do not show creep deformation when subjected to tensile stresses under ambient temperature. MC2010 also mentions that fibre materials with a Young's modulus that is significantly affected by time and/or thermo-hygrometrical phenomena are not covered. In the case of macro-synthetic fibres (MSFs) it is thus of interest to verify the creep behaviour in order to 


\section{Offprint provided courtesy of www.icevirtuallibrary.com Author copy for personal use, not for distribution}

guarantee their load transfer capacity and ability to control crack widths.

Mackay and Trottier (2004) reported a stable evolution of post-cracking flexural creep of concrete beams reinforced with steel and synthetic fibres statically loaded up to $60 \%$ of residual strength over more than a year. Bernard (2010), investigating the magnitude of time-dependent post-crack deflections in shotcrete panels reinforced with steel fibres and MSFs, found that for narrow initial crack widths and load ratios up to $50 \%$ of static residual capacity, the steel fibre reinforced shotcrete panels exhibited a stable creep behaviour and, under many circumstances, the macro-synthetic FRC exhibited a higher degree of creep crack widening than steel FRC. However, studying beams loaded up to $50 \%$ of their residual capacity at a crack opening of $1.5 \mathrm{~mm}$, Kanstad and Žirgulis (2012) found no differences in the creep behaviour between steel fibres and MSFs, and the residual capacity was not significantly modified by long-term loading.

Previous research on cracked steel FRC (Arango, 2010; Arango et al., 2012; García-Taengua et al., 2014) found low coefficients of creep at different long-term load levels for a $90 \mathrm{~d}$ period, but the type of fibre, the load level and the concrete strength significantly affected the creep behaviour. The authors concluded that the use of fibres, even at low contents, is a good strategy to control flexural creep in the cracked state.

Another study on steel FRC (Zerbino and Barragán, 2012) concluded that stable responses appear for initial crack openings of less than $0.5 \mathrm{~mm}$ when applying stresses equal to the stress level at the end of pre-cracking tests and, for crack openings larger than $0.5 \mathrm{~mm}$, sustained stresses lower than $50 \%$ of the residual strength corresponding to a crack opening of $3.5 \mathrm{~mm}$ were recommended.
The benefits of combining FRC and conventional reinforced concrete in order to reduce deformations and crack widths have also been demonstrated. After 100 cycles of loading, Nakov and Markovski (2012) found that the incorporation of $30 \mathrm{~kg} / \mathrm{m}^{3}$ and $60 \mathrm{~kg} / \mathrm{m}^{3}$ of steel fibres reduced deflections by $16 \%$ and $27 \%$ and reduced crack widths by $24 \%$ and $59 \%$ respectively. Similar conclusions were obtained by Vasanelli et al. (2013) in a study of macro-synthetic FRC and steel FRC beams submitted to long-term loads in a marine environment; contrary to what occurs in conventional reinforced concrete, the incorporation of fibres led to a stabilisation of crack widths after 10 months under load. Buratti and Mazzotti (2012) showed that although deformability increased, the residual strength capacity was not affected after the application of long-term loads; their results indicate that the steel fibres reduced the deferred strains.

Considering the potential applications of the many new MSFs that are available and the limitations of MC2010, study of the creep behaviour of cracked FRC becomes relevant. This paper presents a study of the creep behaviour of FRC with different types of MSFs in a cracked state. In order to consider the effect of environmental conditions, the cracked specimens were exposed to three different environmental conditions (in ambient air in the laboratory, immersed in seawater at $45^{\circ} \mathrm{C}$ and exposed to a $45^{\circ} \mathrm{C}$ air flow) for $90 \mathrm{~d}$.

\section{Materials and method}

\section{Experimental programme}

Five FRCs incorporating $0 \cdot 5 \%$ by volume of different fibres were prepared - four with MSFs (C1, C2, C3 and $\mathrm{C} 4)$ and one with hooked-end steel fibres (C5). Twenty four prisms $(150 \times$ $150 \times 600 \mathrm{~mm})$ and six cylinders $(150 \times 300 \mathrm{~mm})$ were fabricated from each FRC, and all were cured in a moist room for $28 \mathrm{~d}$.

\begin{tabular}{|c|c|c|c|c|c|c|c|}
\hline Age: $d$ & \multicolumn{7}{|c|}{ Specimen conservation and testing programme } \\
\hline $1-28$ & \multicolumn{7}{|c|}{ Moist curing: specimens in humidity chamber at $20^{\circ} \mathrm{C}$; RH > 95\% } \\
\hline 28 & \multirow{3}{*}{ 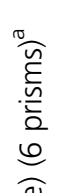 } & \multicolumn{6}{|c|}{ All specimens cracked up to $0.5 \mathrm{~mm}$ CMOD (24 prisms) } \\
\hline $29-120$ & & \multicolumn{6}{|c|}{ Treatment group conditions of cracked specimens } \\
\hline & & \multicolumn{2}{|l|}{$\begin{array}{l}\text { Group L (6 prisms) } \\
\text { in air in laboratory }\end{array}$} & \multicolumn{2}{|c|}{$\begin{array}{l}\text { Group W (6 prisms) } \\
\text { immersed in seawater at } 45^{\circ} \mathrm{C}\end{array}$} & \multicolumn{2}{|c|}{$\begin{array}{l}\text { Group T (6 prisms) } \\
\text { exposed to } 45^{\circ} \mathrm{C} \text { air flow }\end{array}$} \\
\hline \multirow[t]{2}{*}{$120-210$} & $\widehat{\Theta}$ & \multicolumn{6}{|c|}{ Specimens conserved in creep chamber at $20^{\circ} \mathrm{C}$ and $60 \% \mathrm{RH}$} \\
\hline & 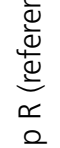 & $\begin{array}{l}\text { Group LC } \\
\text { Creep loading } \\
\text { (3 prisms) }\end{array}$ & $\begin{array}{l}\text { Group LU } \\
\text { Unloaded } \\
\text { (3 prisms) }\end{array}$ & $\begin{array}{l}\text { Group WC } \\
\text { Creep loading } \\
\text { (3 prisms) }\end{array}$ & $\begin{array}{l}\text { Group WU } \\
\text { Unloaded } \\
\text { (3 prisms) }\end{array}$ & $\begin{array}{l}\text { Group TC } \\
\text { Creep loading } \\
\text { (3 prisms) }\end{array}$ & $\begin{array}{l}\text { Group TU } \\
\text { Unloaded } \\
\text { (3 prisms) }\end{array}$ \\
\hline 210 & $\begin{array}{l}\overline{\overline{0}} \\
\frac{0}{0}\end{array}$ & Unloading & Snecimens & Unloading & $4 \mathrm{~mm} C \mathrm{CMO}$ & Unloading & \\
\hline
\end{tabular}

after unloading, at $28 \mathrm{~d}$, the bending test was completed up to $5 \mathrm{~mm} C \mathrm{MOD}$ on the group $\mathrm{R}$ specimens 


\section{Offprint provided courtesy of www.icevirtuallibrary.com Author copy for personal use, not for distribution}

The compressive strength was then measured using three cylinders as per standard methods, and the strength and residual stress parameters in bending were obtained on six prisms following EN 14651 (BSI, 2005). In addition, and using the same procedure, the remaining 18 prisms were pre-cracked up to $0.5 \mathrm{~mm}$ crack mouth opening displacement (CMOD) and then unloaded. The cracked prisms were classified into three groups of six specimens and exposed to different environmental conditions for $90 \mathrm{~d}$. After this period, they were placed

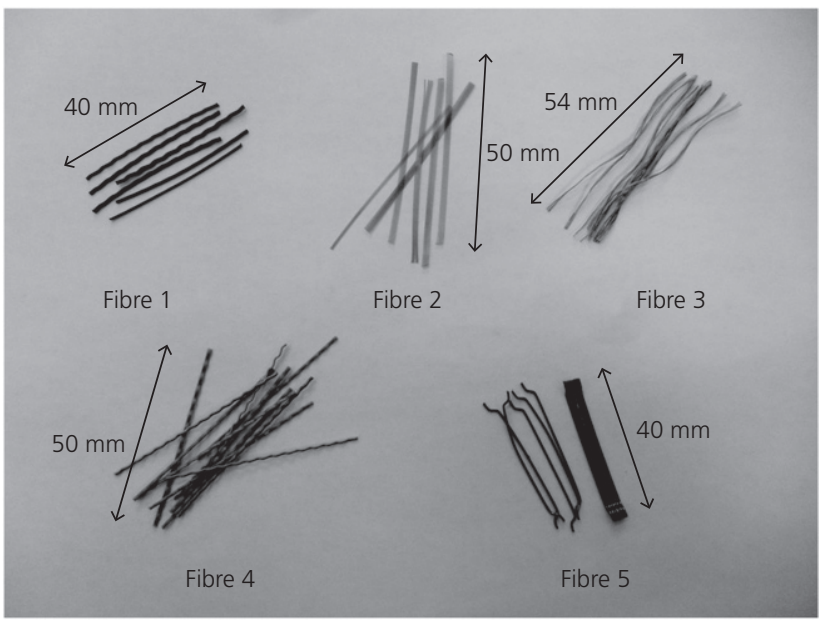

Figure 1. Used fibres in a dry room $\left(20^{\circ} \mathrm{C}\right.$ temperature, $60 \%$ relative humidity $\left.(\mathrm{RH})\right)$ where creep tests were performed on three prisms per group while the other three beams remained unloaded. At $210 \mathrm{~d}$ after casting, bending tests were performed on all the cracked prisms up to a CMOD of $4 \mathrm{~mm}$ in order to evaluate their residual strength capacity. The general scheme of the experimental programme is summarised in Table 1.

\section{Materials}

All the FRCs were prepared by incorporating different fibres to the same base mixture, a self-compacting concrete of $650 \mathrm{~mm}$ slump flow. Commercial fibres from different producers were used (see Figure 1 and Table 2). The base mixture was prepared using $290 \mathrm{~kg} / \mathrm{m}^{3}$ CEM I $52 \cdot 5$ type Portland cement, $100 \mathrm{~kg} / \mathrm{m}^{3}$ limestone filler, $900 \mathrm{~kg} / \mathrm{m}^{3}$ crushed sand, $770 \mathrm{~kg} / \mathrm{m}^{3}$ gravel (12 mm maximum size) and an appropriate dosage of modified polycarboxylate-based superplasticiser in order to achieve values of slump flow near the minimum requirements for selfcompactability. Table 3 shows the fresh properties and the $28 \mathrm{~d}$ compressive strengths of each FRC. As expected, each type of fibre affected the fluidity in a different way.

\section{Exposure environments}

Three different environments were selected as follows.

Laboratory air (group L). In these non-aggressive conditions, only a small amount of matrix-aggregate

\begin{tabular}{|c|c|c|c|c|c|}
\hline & Fibre 1 & Fibre 2 & Fibre 3 & Fibre 4 & Fibre 5 \\
\hline Material & Polypropylene & Polypropylene & Polypropylene copolymer & Polypropylene & Steel \\
\hline Length: mm & 40 & 50 & 54 & 50 & 40 \\
\hline Diameter: mm & 0.75 & 0.62 & 0.30 & $0 \cdot 70$ & 0.62 \\
\hline Slenderness & 53 & 81 & 158 & 71 & 65 \\
\hline Tensile strength: MPa & 338 & 394 & $570-660$ & 412 & 1225 \\
\hline Shape & Crimped & - & Torsioned & Crimped & Hooked-end \\
\hline Elongation: \% & $15-25 \%$ & - & - & $15 \%$ & - \\
\hline Elastic modulus: GPa & $1 \cdot 55$ & $4 \cdot 4$ & 5 & - & 210 \\
\hline Melting point: ${ }^{\circ} \mathrm{C}$ & $150-170$ & 160 & $325-335$ & - & - \\
\hline Fibres per kg & - & 73000 & 221000 & - & 10000 \\
\hline
\end{tabular}

Table 2. Details of fibres used

\begin{tabular}{|c|c|c|c|c|c|}
\hline FRC & C1 & $\mathrm{C} 2$ & C3 & C4 & C5 \\
\hline Fibres: kg/m & $4 \cdot 5$ & $4 \cdot 5$ & $4 \cdot 5$ & $4 \cdot 5$ & 39 \\
\hline Superplasticiser: kg/m³ & 8.6 & $5 \cdot 9-8 \cdot 6$ & $7 \cdot 3-9 \cdot 9$ & $7 \cdot 0-8 \cdot 6$ & $6 \cdot 5-8 \cdot 6$ \\
\hline Slump flow diameter: $\mathrm{mm}$ & 535 & 495 & 505 & 500 & 540 \\
\hline $28 \mathrm{~d}$ compressive strength: $\mathrm{MPa}$ & $42 \cdot 0$ & $37 \cdot 1$ & $40 \cdot 1$ & $42 \cdot 1$ & $41 \cdot 4$ \\
\hline $28 \mathrm{~d}$ bending strength, $f_{\mathrm{L}}: \mathrm{MPa}$ & $3 \cdot 38$ & $3 \cdot 45$ & $3 \cdot 53$ & $3 \cdot 26$ & $3 \cdot 80$ \\
\hline $28 \mathrm{~d}$ residual strength, $f_{\mathrm{R} 1}: \mathrm{MPa}$ & $1 \cdot 15$ & $1 \cdot 76$ & $1 \cdot 62$ & $0 \cdot 87$ & $5 \cdot 14$ \\
\hline
\end{tabular}

Table 3. Main characteristics of the studied concretes 


\section{Offprint provided courtesy of www.icevirtuallibrary.com Author copy for personal use, not for distribution}

interfaces or fibre-matrix micro-cracking due to drying shrinkage could appear.

- Seawater (group W). The prisms were immersed in artificial seawater at $45^{\circ} \mathrm{C}$. An isolated vessel with a water heating and recirculation system and proper temperature control sensors was used. Such conditions can affect both the cementitious matrix and the fibres (mainly steel fibres). In accordance with ASTM D1141-98 (ASTM, 2008), $24.72 \mathrm{~g} / \mathrm{l}$ of $\mathrm{NaCl}, 0.67 \mathrm{~g} / \mathrm{l}$ of $\mathrm{KCl}, 1.36 \mathrm{~g} / \mathrm{l}$ of $\mathrm{CaCl}_{2} \cdot 2 \mathrm{H}_{2} \mathrm{O}$, $4.66 \mathrm{~g} / \mathrm{l}$ of $\mathrm{MgCl}_{2} \cdot 6 \mathrm{H}_{2} \mathrm{O}, 6 \cdot 29 \mathrm{~g} / \mathrm{l}$ of $\mathrm{MgSO}_{4} \cdot 7 \mathrm{H}_{2} \mathrm{O}$ and $0 \cdot 18 \mathrm{~g} / \mathrm{l}$ of $\mathrm{NaHCO}_{3}$ were used to prepare the artificial seawater.

- Hot air flow (group T). The prisms were placed in an isolated chamber under a $45^{\circ} \mathrm{C}$ air flow. This condition was selected considering that, in addition to the drying shrinkage effects, hot air can affect the deformability or the bond of the MSFs.

In all cases $(\mathrm{L}, \mathrm{W}$ and $\mathrm{T})$ the prisms were turned through $90^{\circ}$ on the lateral axis to avoid load effects on the current crack.

\section{Creep tests}

Creep tests were conducted following the procedure proposed by Arango et al. (2012). Creep frames were made from steel profiles to enable loading of three specimens forming a column, guaranteeing test stability over time (Figure 2). Four-point loading over a span of $450 \mathrm{~mm}$ was used. The sustained load was adjusted to apply to each prism a nominal stress equal to $70 \%$ of the average residual strength at a CMOD of $0.5 \mathrm{~mm}$ obtained during the pre-cracking of all the specimens from the corresponding group. A data acquisition system was used to record data from load cells placed in the top of the frames; displacement transducers measured the CMOD for each specimen and temperature and humidity transducers controlled the environmental room conditions. After $90 \mathrm{~d}$, the prisms were unloaded; the measurement and acquisition of CMOD data was continued for $48 \mathrm{~h}$ to evaluate the residual deformation.

\section{Creep analysis parameters}

Figure 3 shows an idealised stress-crack opening curve for a specimen, including all phases of the testing process (precracking, creep, post-creep unloading and post-creep testing until failure). The parameters considered for analysing the creep behaviour of concrete were as follows.

- Pre-cracking up to a nominal CMOD of $0.5 \mathrm{~mm}$. The following parameters were identified: $f_{\mathrm{L}}$, first-peak flexural strength (point A); $w_{\mathrm{p}}$, maximum crack opening; $f_{\mathrm{R} 1 \text {, }}$, residual stress at $w_{\mathrm{p}}$ (point $\left.\mathrm{B}\right) ; w_{\mathrm{pr}}$, residual crack opening after unloading (point $\mathrm{C}$ ).

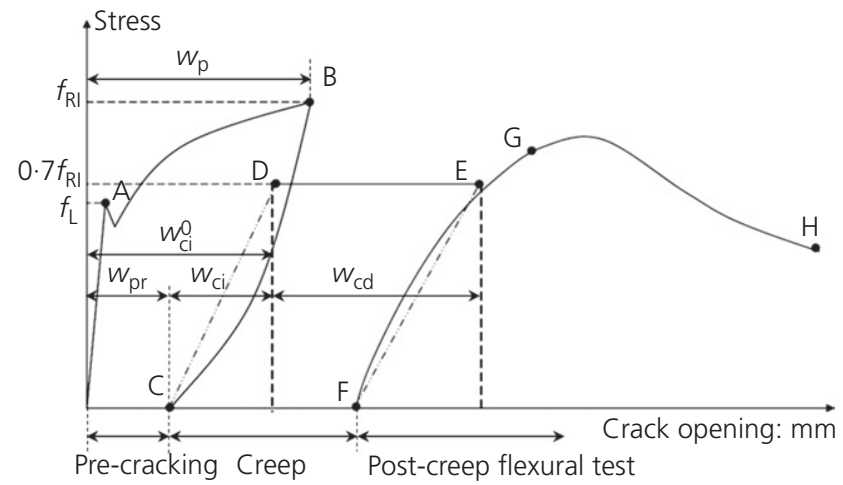

Figure 3. Definition of crack opening parameters for creep test
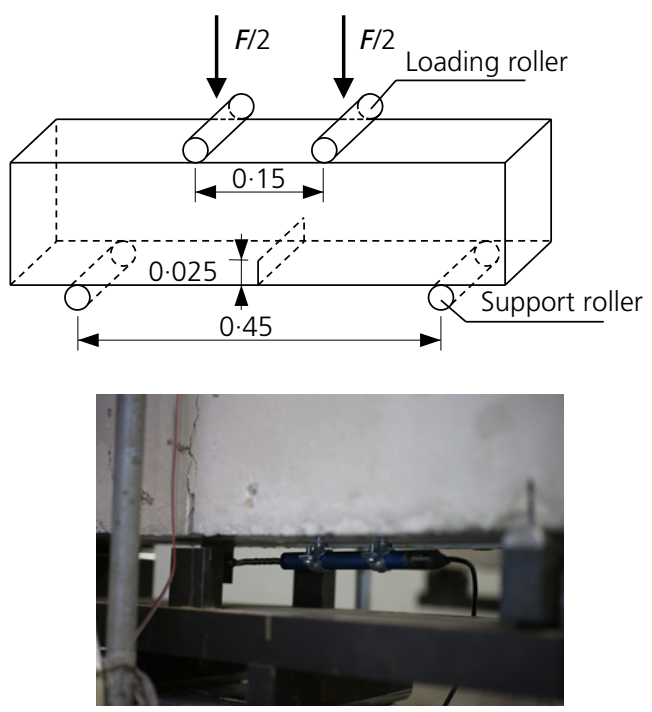

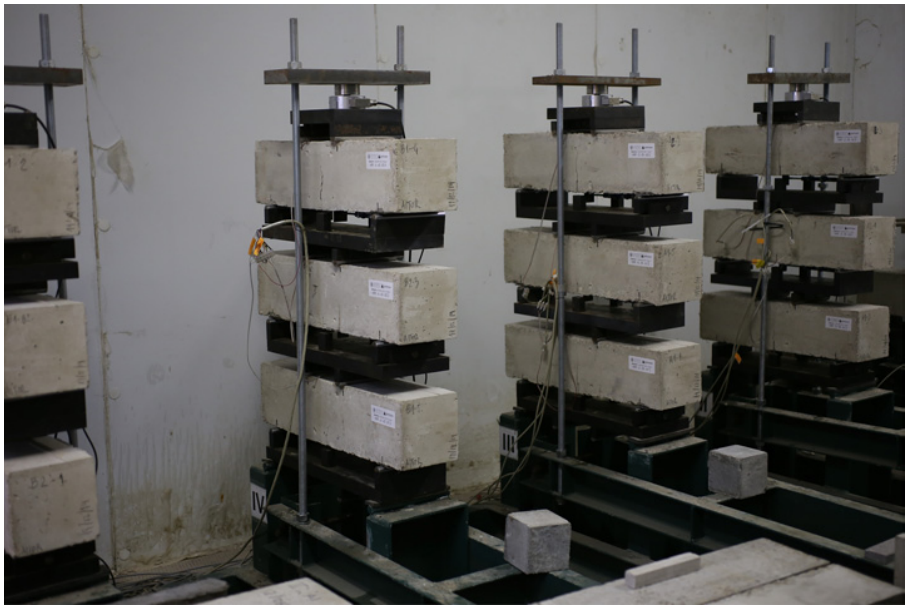

Figure 2. Load configuration and measurement transducers during creep tests (dimensions in $\mathrm{m}$ ) 


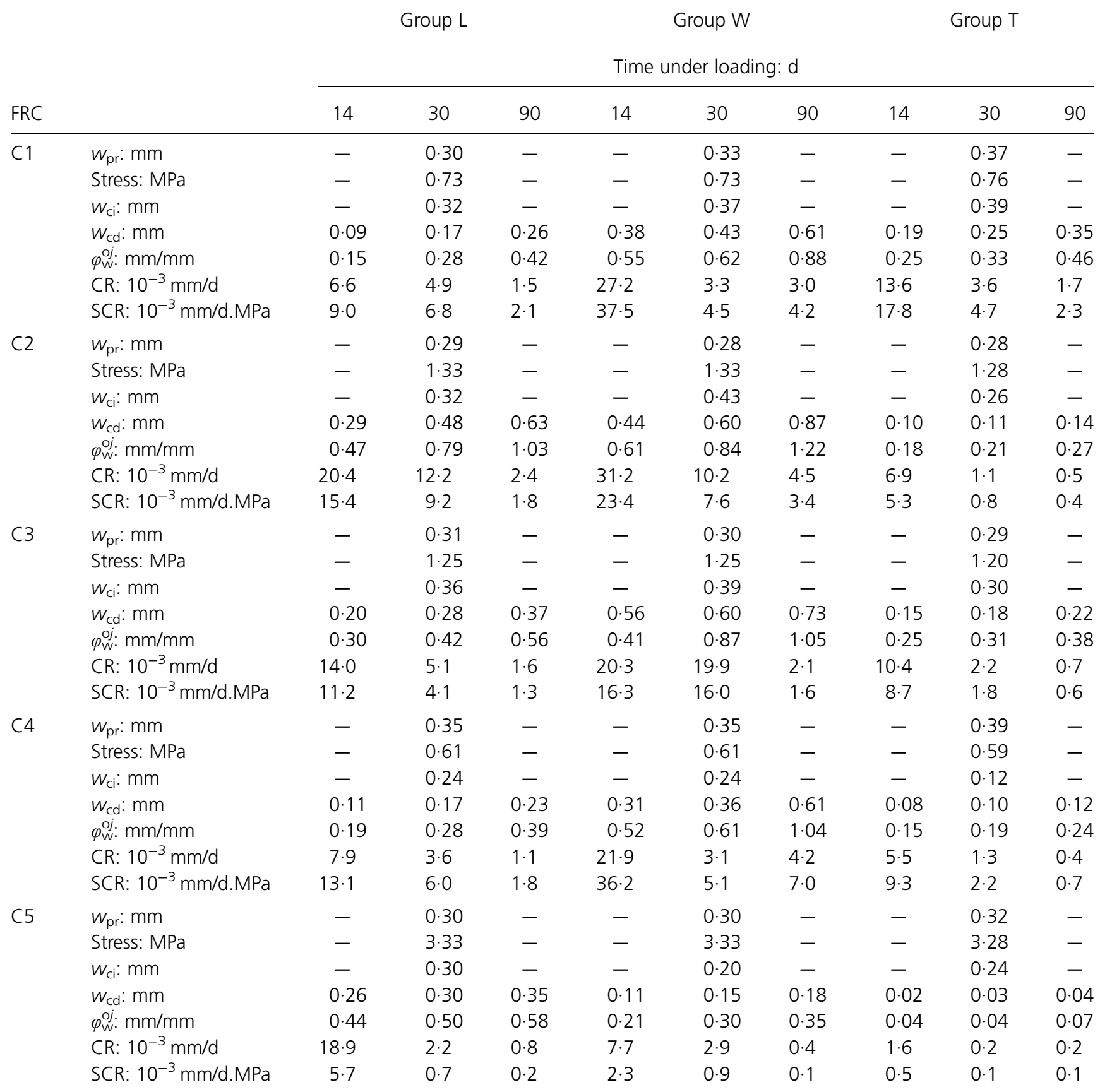

Table 4. Creep tests results

Creep test - a sustained stress level of $0 \cdot 7 f_{\mathrm{R} 1}$ was adopted. The parameters considered were: $w_{\text {ci }}$, instantaneous crack opening in the loading process (point D); $w_{\text {cd }}^{j}$, deferred crack opening at time $j ; w_{\text {cd }}$, deferred crack opening at the time previous to unloading (point E). The creep coefficient at time $j\left(\varphi_{\mathrm{w}}^{\mathrm{oj}}\right)$ is defined as deferred/instantaneous crack opening, where the instantaneous crack opening $\left(w_{\mathrm{ci}}^{\mathrm{o}}\right)$ is referred to the origin $\left(w_{\mathrm{ci}}^{\mathrm{o}}=w_{\mathrm{ci}}+w_{\mathrm{pr}}\right)$.
Post-creep flexural test. This process evaluates the residual strength of the specimens by composing the total stresscrack opening curve (points $\mathrm{F}$ to $\mathrm{H}$ ); residual strength parameters for greater CMODs can be calculated.

The strength parameters considered in the creep test can be compared with the values obtained in EN 14651 standard tests. The first crack strength $\left(f_{\mathrm{L}}\right)$ and the residual strength 


\section{Offprint provided courtesy of www.icevirtuallibrary.com Author copy for personal use, not for distribution}

$\left(f_{\mathrm{R} 1}\right)$ are exactly those measured during the pre-cracking process. The residual stress calculated for a CMOD of $1.5 \mathrm{~mm}$ is not considered because the prisms suffer significant crack opening during the pre-cracking and the creep process; usually, in the final bending test, they achieve this CMOD during the ascending branch (points $\mathrm{F}$ to $\mathrm{G}$ ). However, this is not the case of residual strengths corresponding to wider CMODs, which can be used to evaluate the residual capacity of the prisms after the creep tests. As the residual stress $f_{\mathrm{R} 3}$, calculated for a CMOD of $2.5 \mathrm{~mm}$, is applied in MC2010 for FRC classification, it is the value analysed in this work.

\section{Analysis of results}

Table 3 shows the results of concrete compressive strength obtained from the cylinders and the first-crack strengths $\left(f_{\mathrm{L}}\right)$ and residual stresses $\left(f_{\mathrm{R} 1}\right)$ from the prisms. These results correspond to the mean values from all the beams tested at $28 \mathrm{~d}$ (six complete EN 14651 tests for FRC characterisation and 18 only pre-cracked). It can be seen that all the FRCs had a similar concrete compressive strength, in the range $37 \cdot 1-42 \cdot 1 \mathrm{MPa}$,

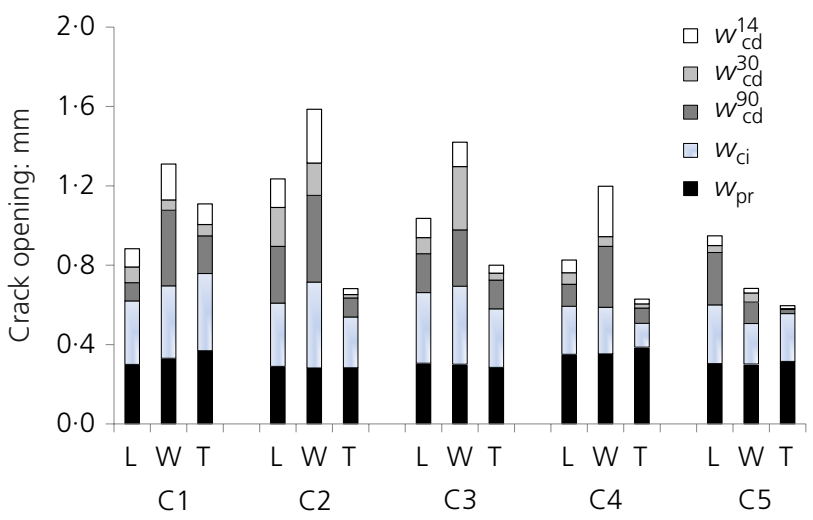

(a)

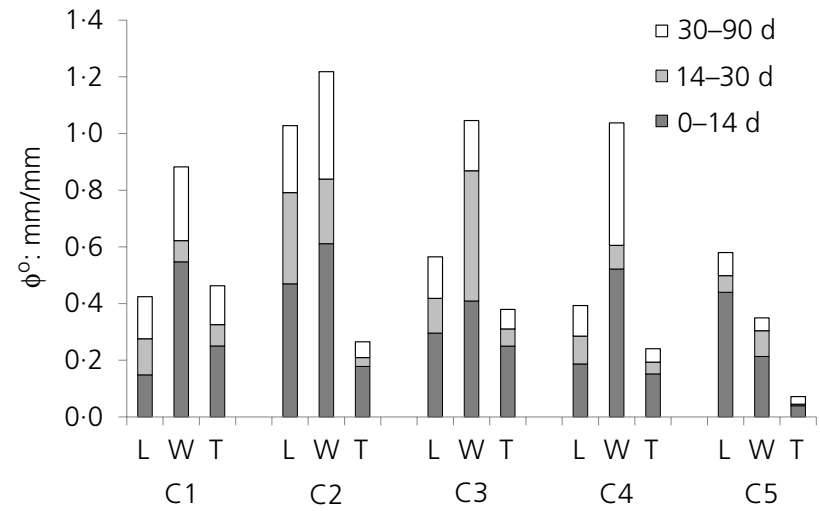

(b)

Figure 4. (a) Residual crack opening after unloading $\left(w_{\text {pr }}\right)$, instantaneous crack opening at loading $\left(w_{\mathrm{ci}}\right)$ and deferred crack opening after $j$ days $\left(w_{c d}^{j}\right)$. (b) Creep coefficient after 14, 30 and $90 \mathrm{~d}$ while the bending strength varied between $3.26 \mathrm{MPa}$ and $3 \cdot 80 \mathrm{MPa}$

The residual capacity depends on the type of fibre used, as expected. The highest values correspond to the steel FRC (C5), which showed hardening type post-peak behaviour. For concretes with MSFs, $\mathrm{C} 2$ and $\mathrm{C} 3$ showed greater residual strength, whereas $\mathrm{C} 1$ and $\mathrm{C} 4$ had values of $f_{\mathrm{R} 1}$ lower than $40 \%$ of $f_{\mathrm{L}}$, which indicates low structural post-peak capacity.

The creep test results are summarised in Table 4 . The residual crack opening after unloading $\left(w_{\mathrm{pr}}\right)$, the applied stress during creep tests, the instantaneous crack opening in the loading process $\left(w_{\mathrm{ci}}\right)$ and the deferred crack opening $\left(w_{\mathrm{cd}}\right)$ during the periods $0-14 \mathrm{~d}, 14-30 \mathrm{~d}$ and $30-90 \mathrm{~d}$ are listed. Table 4 also shows the creep coefficient $\left(\varphi_{\mathrm{w}}^{\mathrm{oj}}\right)$, the creep rate $(\mathrm{CR}$, the ratio between deferred strain and time period) and, as the FRCs were subjected to different stresses, the specific creep rate (SCR, ratio between CR and applied stress).

Figure 4(a) compares the results of CMOD evolution for each FRC, and shows the residual crack opening after precracking $\left(w_{\text {pr }}\right)$, the instantaneous crack opening at loading $\left(w_{\mathrm{ci}}\right)$ and the deferred crack openings $\left(w_{\mathrm{cd}}\right)$ at $14 \mathrm{~d}, 30 \mathrm{~d}$ and $90 \mathrm{~d}$. After pre-cracking, the residual cracks were similar in all

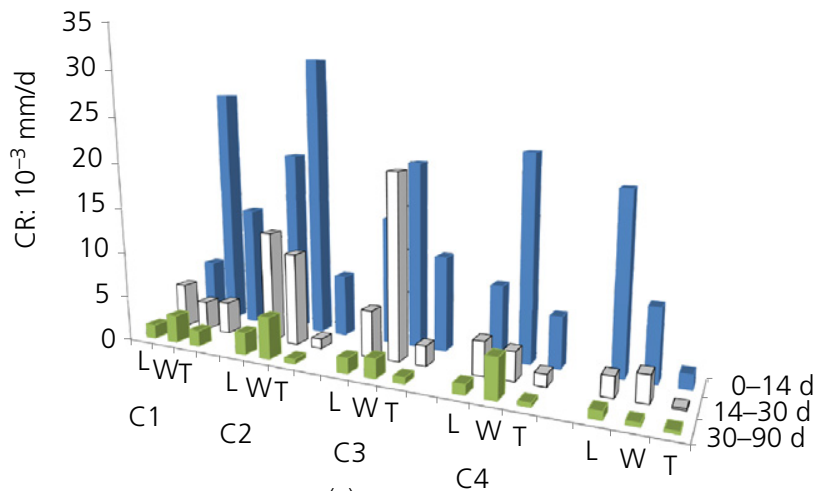

(a)

C5

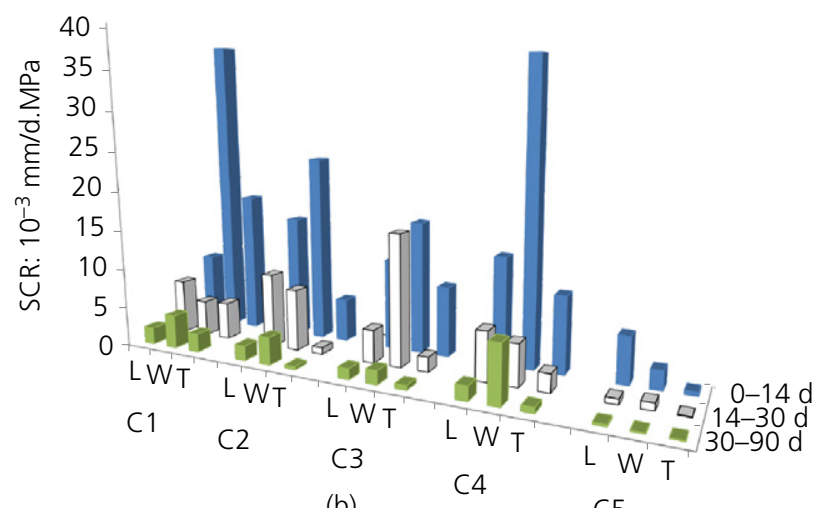

(b)

Figure 5. Creep test results: (a) creep rate; (b) specific creep rate 


\section{Offprint provided courtesy of www.icevirtuallibrary.com Author copy for personal use, not for distribution}

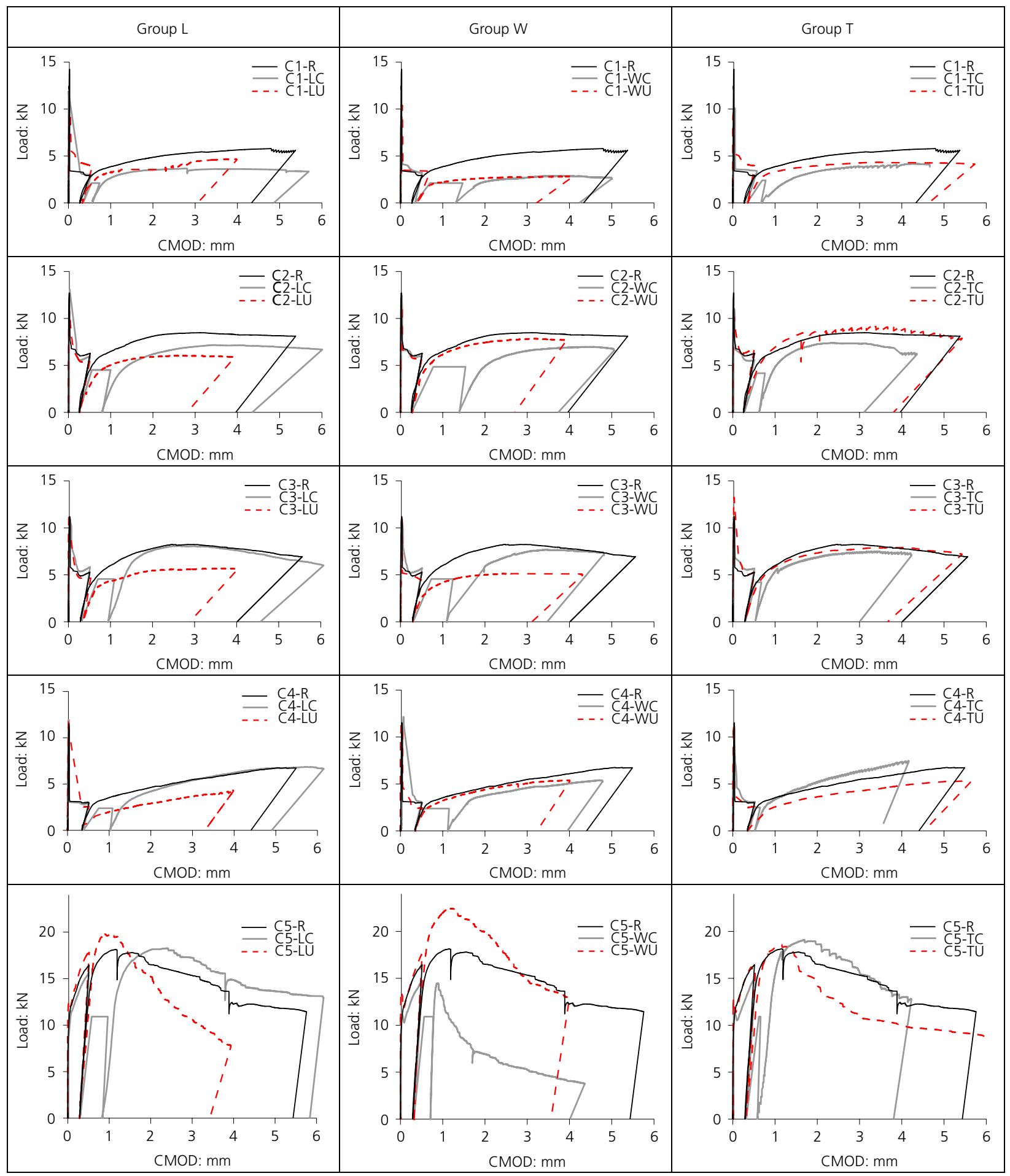

Figure 6. Typical load-CMOD curves

FRCs and close to $0.3 \mathrm{~mm}$. In $\mathrm{C} 2$ and $\mathrm{C} 3$, the instantaneous crack openings after loading were greater in group $\mathrm{W}$ than in groups $\mathrm{L}$ or $\mathrm{T}$, which can be associated with some reinforcement degradation; these FRCs also showed higher creep strains. Comparing macro-synthetic and steel fibres, the deferred strains were smaller in $\mathrm{C} 5$, and mainly those corresponding to groups W and T. Negative effects in the specimens subjected to hot air flow (group T) were not found - on the contrary, they usually showed lower values of creep. Among the tests on concretes with added MSFs, those corresponding to group W 
showed the greater creep values. However, it should be noted that the deferred crack openings were always less than $1 \mathrm{~mm}$.

The creep coefficients of each FRC are compared in Figure 4(b), and the values confirm the observations from Figure 4(a); that is, the group W concretes containing MSFs showed the greater creep values. Figure 4(b) also shows that there is a clear effect from the type of fibre and the environmental conditions. A temperature of $45^{\circ} \mathrm{C}$ did not have a detrimental effect on the creep behaviour of the tested MSFs; on the contrary, this condition probably enhances matrix strength. Part of the increases in creep strains of the specimens immersed in seawater (group W) can be associated with a drying process together with the long-term load application. The creep coefficients of the steel FRCs (C5) were in most cases smaller than those of the corresponding concretes with MSFs: in the case of group $\mathrm{W}$, the coefficients of $\mathrm{C} 2, \mathrm{C} 3$ and $\mathrm{C} 4$ were up to three times higher than those of $\mathrm{C} 5$; with the exception of $\mathrm{C} 2$, the creep coefficients were similar in group L; for group $\mathrm{T}$, the creep coefficients for all FRCs with MSFs were close and markedly greater than the creep coefficient of steel FRC.

Figures 5(a) and 5(b) compare the values of CR and SCR respectively for different periods of loading (0-14 d, 14-30 d and $30-90 \mathrm{~d}$ ) for groups $\mathrm{L}, \mathrm{W}$ and $\mathrm{T}$ of the five FRCs. As expected, CR decreased after the first $14 \mathrm{~d}$ of loading in all cases (except for a comparison of the 14-30 d and 30-90 d periods for group $\mathrm{W}$ of $\mathrm{C} 4)$. The SCR values showed greater differences between macro-synthetic and steel fibre creep behaviour, being up to 15 times smaller in the latter. $\mathrm{C} 1$ and $\mathrm{C} 4$ showed higher SCR values than $\mathrm{C} 2$ and $\mathrm{C} 3$, indicating differences in their residual capacity as discussed later in the paper. In addition, the SCR values in the macro-synthetic FRCs decreased from group $\mathrm{W}$ to group $\mathrm{L}$, with the lowest values attained by the group $\mathrm{T}$ specimens. The greater creep observed in group $\mathrm{W}$ could be associated with loss of water during creep testing.

Figure 6 shows the stress-CMOD curves for each FRC, those corresponding to the six complete bending tests performed at $28 \mathrm{~d}$ (group R) and those of the pre-cracked beams; the latter were built from the pre-cracking test plus the creep test (when corresponding) plus the post-creep bending test of the beam that showed intermediate behaviour of each group. It should be noted that no beam failures occurred for the sustained load conditions adopted (near $0 \cdot 7 f_{\mathrm{R} 1}$ ). It can be seen that there was a significant increase in crack opening in the case of the prisms submitted to long-term loadings, mainly in the case of the macro-synthetic FRCs (C1-C4).

The mean results of the strength and residual capacity of each group are indicated in Table 5 in terms of the first-crack strength $\left(f_{\mathrm{L}}\right)$, the residual stresses $f_{\mathrm{R} 1}$ and $f_{\mathrm{R} 3}$ and the ratios $f_{\mathrm{R} 1} / f_{\mathrm{L}}$ and $f_{\mathrm{R} 3} / f_{\mathrm{R} 1}$. It should be noted that when comparing the bending behaviour of the pre-cracked beams with those tested at $28 \mathrm{~d}$, no significant degradation effects on the bending

\begin{tabular}{|c|c|c|c|c|c|c|}
\hline FRC & Group & $f_{\mathrm{L}}: \mathrm{MPa}$ & $f_{\mathrm{R} 1}: \mathrm{MPa}$ & $f_{\mathrm{R} 3}: \mathrm{MPa}$ & $f_{\mathrm{R} 1} / f_{\mathrm{L}}$ & $f_{\mathrm{R} 3} / f_{\mathrm{R} 1}$ \\
\hline \multirow[t]{7}{*}{ C1 } & $\mathrm{R}$ & $3 \cdot 84$ & 1.00 & 1.65 & 0.26 & 1.65 \\
\hline & LU & 3.06 & $1 \cdot 18$ & 1.09 & $0 \cdot 39$ & 0.92 \\
\hline & LC & $3 \cdot 40$ & 1.00 & 1.08 & 0.29 & 1.08 \\
\hline & WU & $3 \cdot 11$ & 1.05 & 0.89 & $0 \cdot 34$ & 0.85 \\
\hline & WC & $3 \cdot 11$ & $1 \cdot 17$ & 1.05 & 0.38 & 0.90 \\
\hline & TU & $3 \cdot 14$ & $1 \cdot 26$ & $1 \cdot 40$ & 0.40 & $1 \cdot 11$ \\
\hline & $\mathrm{TC}$ & $3 \cdot 32$ & $1 \cdot 20$ & $1 \cdot 28$ & 0.36 & 1.07 \\
\hline \multirow[t]{7}{*}{$C 2$} & $\mathrm{R}$ & $3 \cdot 32$ & $1 \cdot 79$ & $2 \cdot 58$ & 0.54 & 1.44 \\
\hline & LU & $3 \cdot 36$ & $1 \cdot 53$ & 1.66 & 0.46 & 1.08 \\
\hline & LC & $3 \cdot 60$ & $1 \cdot 81$ & $1 \cdot 91$ & 0.50 & 1.06 \\
\hline & WU & $3 \cdot 25$ & $1 \cdot 59$ & 1.98 & 0.49 & $1 \cdot 25$ \\
\hline & WC & $3 \cdot 53$ & $1 \cdot 82$ & $1 \cdot 74$ & 0.52 & 0.96 \\
\hline & TU & $3 \cdot 21$ & $1 \cdot 72$ & $2 \cdot 17$ & 0.54 & $1 \cdot 26$ \\
\hline & $\mathrm{TC}$ & $3 \cdot 74$ & 1.91 & $2 \cdot 52$ & 0.51 & $1 \cdot 32$ \\
\hline \multirow[t]{7}{*}{ C3 } & $\mathrm{R}$ & $3 \cdot 21$ & 1.65 & $2 \cdot 22$ & 0.51 & $1 \cdot 35$ \\
\hline & LU & $3 \cdot 60$ & 1.47 & 1.95 & 0.41 & $1 \cdot 33$ \\
\hline & LC & $3 \cdot 32$ & $1 \cdot 74$ & $2 \cdot 11$ & 0.52 & $1 \cdot 21$ \\
\hline & WU & $3 \cdot 55$ & $1 \cdot 76$ & $2 \cdot 08$ & 0.50 & $1 \cdot 18$ \\
\hline & WC & $3 \cdot 80$ & $1 \cdot 73$ & 1.95 & 0.46 & $1 \cdot 13$ \\
\hline & TU & $4 \cdot 01$ & $1 \cdot 53$ & $2 \cdot 08$ & 0.38 & $1 \cdot 36$ \\
\hline & $\mathrm{TC}$ & $3 \cdot 61$ & $1 \cdot 84$ & $2 \cdot 44$ & 0.51 & $1 \cdot 33$ \\
\hline \multirow[t]{7}{*}{ C4 } & $\mathrm{R}$ & $2 \cdot 88$ & $0 \cdot 82$ & $1 \cdot 27$ & 0.28 & $1 \cdot 55$ \\
\hline & LU & $3 \cdot 85$ & 1.04 & 1.48 & 0.27 & 1.42 \\
\hline & LC & $3 \cdot 33$ & $0 \cdot 86$ & $1 \cdot 40$ & 0.26 & 1.63 \\
\hline & WU & $3 \cdot 34$ & 0.79 & $1 \cdot 30$ & 0.24 & 1.65 \\
\hline & WC & $3 \cdot 49$ & 0.90 & $1 \cdot 13$ & 0.26 & $1 \cdot 26$ \\
\hline & TU & 3.44 & 0.95 & 1.43 & 0.28 & 1.51 \\
\hline & $\mathrm{TC}$ & 3.09 & 0.87 & $1 \cdot 50$ & 0.28 & 1.72 \\
\hline \multirow[t]{7}{*}{$C 5$} & $\mathrm{R}$ & $3 \cdot 50$ & $4 \cdot 72$ & $4 \cdot 80$ & $1 \cdot 35$ & 1.02 \\
\hline & LU & $3 \cdot 78$ & $5 \cdot 54$ & $4 \cdot 41$ & 1.47 & 0.80 \\
\hline & LC & $3 \cdot 33$ & $4 \cdot 77$ & 5.07 & $1 \cdot 43$ & 1.06 \\
\hline & WU & $4 \cdot 39$ & $5 \cdot 79$ & $4 \cdot 86$ & $1 \cdot 32$ & 0.84 \\
\hline & WC & $3 \cdot 37$ & 4.65 & $2 \cdot 00$ & $1 \cdot 38$ & 0.43 \\
\hline & TU & $3 \cdot 72$ & $4 \cdot 89$ & $3 \cdot 78$ & $1 \cdot 31$ & 0.77 \\
\hline & $\mathrm{TC}$ & $4 \cdot 33$ & 5.09 & $4 \cdot 84$ & $1 \cdot 18$ & 0.95 \\
\hline
\end{tabular}

Table 5. First-peak strength and residual strength parameters

capacity were found for the unloaded specimens or those subjected to long-term loading. There was a small decrease for group $\mathrm{W}$ specimens of $\mathrm{C} 1$, for both unloaded and loaded specimens. For C5, decreases in residual capacity were not found, with the exception of the loaded specimens of group W where they were significant.

Figure 7 shows the results for $f_{\mathrm{L}}$ and $f_{\mathrm{R} 1}$, indicating the original strength of each group, together with $f_{\mathrm{R} 3}$, which represents the residual capacity of each group of FRC after exposure to different environmental conditions (R, LU, LC, WU, WC, TU, TC). The figure shows that, with the exception of group $\mathrm{W}$ of $\mathrm{C} 5$, there were no effects on the residual capacity $f_{\mathrm{R} 3}$ when loaded and unloaded specimens are compared. 

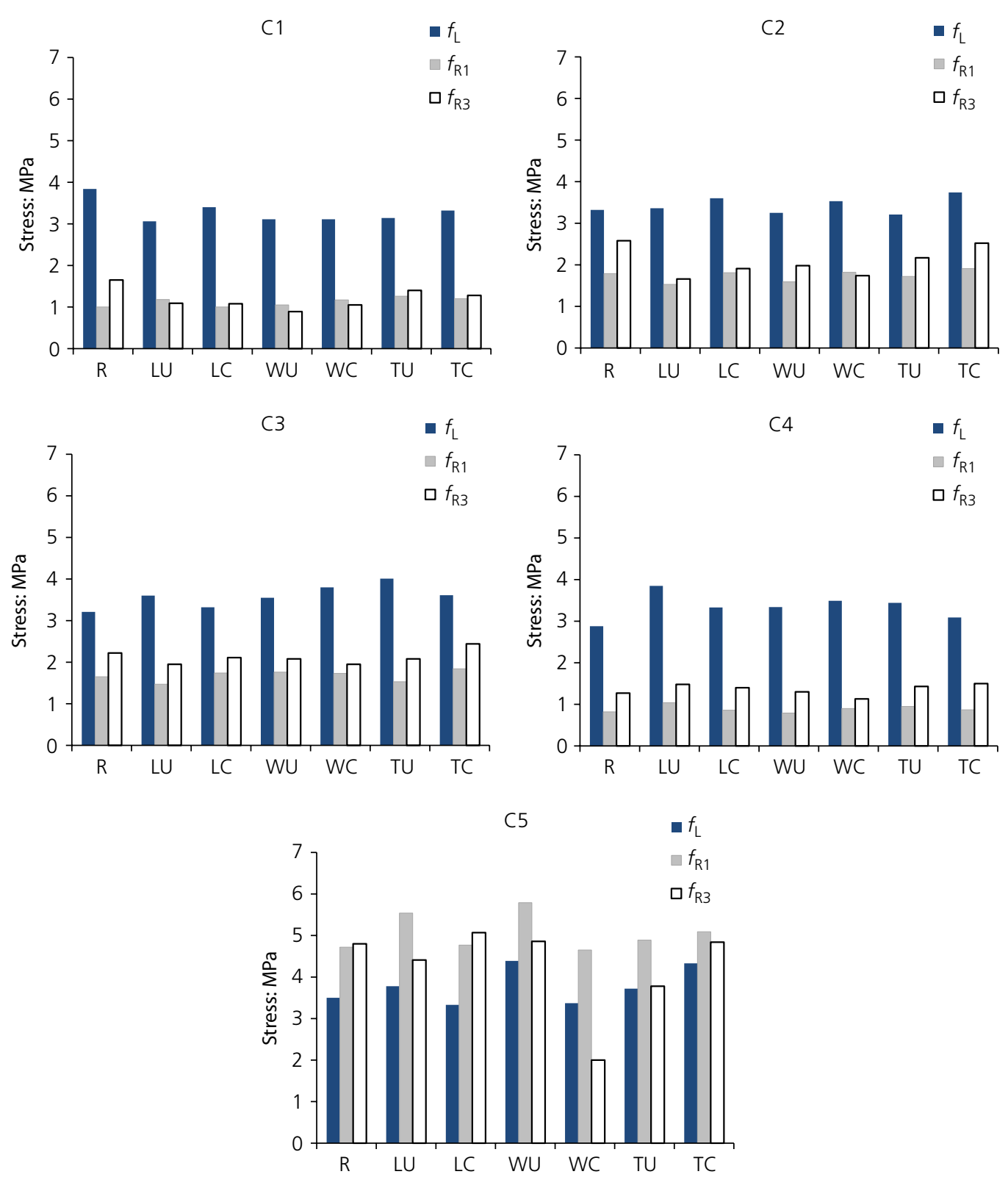

Figure 7. Comparison of first-peak strengths and residual strengths of the different groups

On the contrary, in many cases the residual capacity increased in the prisms subjected to creep. Figures 6 and Figure 7 also show that the residual capacity of the pre-cracked prisms tested at later ages was not modified when compared to the group $\mathrm{R}$ specimens, with the exception of group WC of C5. Regarding macro-synthetic FRCs, there was some decrease in residual capacity of $\mathrm{C} 2$, an even smaller decrease in $\mathrm{C} 1$ in relative terms, and no changes in $\mathrm{C} 3$ and $\mathrm{C} 4$.

Bearing in mind that the variability of the FRCs themselves may lead to some strength differences between the groups of each FRC, Table 5 includes the results of $f_{\mathrm{R} 1}$ as relative values of $f_{\mathrm{L}}$ (representing the base concrete bending strength) and the values of $f_{\mathrm{R} 3}$ relative to $f_{\mathrm{R} 1}$ (representative of the residual capacity of each prism before exposure to different environmental and loading conditions) in order to analyse the influence of these variables. The results show that the $f_{\mathrm{R} 1} / f_{\mathrm{L}}$ ratios were similar in the groups of the same FRC, indicating low variability between the different groups of each FRC. Thus, the effects of ageing in different environments and those related to the application of long-term loads can be analysed from the $f_{\mathrm{R} 3} / f_{\mathrm{R} 1}$ ratios. 


\section{Offprint provided courtesy of www.icevirtuallibrary.com Author copy for personal use, not for distribution}

For the laboratory environment, the $f_{\mathrm{R} 3} / f_{\mathrm{R} 1}$ ratios of LU and LC groups were similar or slightly smaller, indicating that sustained loading did not affect the residual capacity. For $\mathrm{C} 3$, $\mathrm{C} 4$ and $\mathrm{C} 5$, the LC groups had $f_{\mathrm{R} 3} / f_{\mathrm{R} 1}$ ratios similar to those of group $\mathrm{R}$, but were lower in $\mathrm{C} 1$ and $\mathrm{C} 2$.

For the specimens exposed to hot air flow, there were no great differences between TC and TU, and the ratios were similar to the corresponding $\mathrm{L}$ groups (except for $\mathrm{C} 2$ ); there was a reduction in residual capacity when compared with group $\mathrm{R}$ for $\mathrm{C} 1$, and a minor reduction in $\mathrm{C} 2$ and $\mathrm{C} 5$.

Regarding the seawater environment, although great differences were not observed, there was a tendency towards lower ratios when group $\mathrm{W}$ was compared to group $\mathrm{L}$ or group $\mathrm{T}$; the only notable observed degradation was for steel FRC immersed in seawater (C5, group WC).

The experimental work described shows that cracked $(0.5 \mathrm{~mm})$ FRC specimens exposed to different environmental conditions and submitted to long-term bending stresses of $0 \cdot 7 f_{\mathrm{R} 1}$ for $90 \mathrm{~d}$ do not suffer significant modifications to their residual capacity. Although the incorporation of MSFs resulted in greater CMODs than in the case of steel fibres, the creep rate clearly decreased during the first two weeks and, in any case, behaviour inferring the proximity of beam failure was not observed. After immersion in seawater, the concretes reinforced with MSFs showed better behaviour than steel FRC, as expected.

\section{Conclusions}

Creep behaviour in the cracked state and the residual properties of fibre reinforced concrete (FRC) incorporating four different macro-synthetic fibres (MSFs) and one steel fibre were analysed. Before conducting creep tests, cracked specimens were held for $90 \mathrm{~d}$ in three different environments - in air in the laboratory (group L), immersed in seawater at $45^{\circ} \mathrm{C}$ (group W) and exposed to air flow at $45^{\circ} \mathrm{C}$ (group T). The main conclusions from this study are as follows.

- The type of fibre and environmental conditions can affect creep behaviour and the residual response of FRC. However, with differences found among the studied MSFs and only one type of steel fibre analysed, more tests are necessary to generalise criteria in order to predict the behaviour of a specific FRC.

- Creep strains were greater in concretes reinforced with MSFs than concretes reinforced with steel fibres.

- The crack opening rate significantly decreased after the first two weeks under loading, and no risks of failure were detected for the stress level applied ( $70 \%$ of $\left.f_{\mathrm{R} 1}\right)$.

- The crack openings were greatest in group W specimens, followed by those of group L, and lowest in group T specimens.
- The specific creep rate clearly increased in group W specimens of macro-synthetic FRC and decreased by more than an order of magnitude in the steel FRC.

- The residual capacities of cracked macro-synthetic FRCs, even those exposed to seawater, were not significantly affected by long-term loading. On the contrary, there were obvious reductions in the residual capacity of the steel FRC specimens subjected to immersion in seawater.

- For each cracked FRC, the lowest residual capacity usually corresponded to group $\mathrm{W}$ and the greatest to group T. Although there were differences in the creep behaviour of the four macro-synthetic FRCs, the differences were smaller than those observed between each environment.

- Comparing the residual capacity after creep tests of groups $\mathrm{L}, \mathrm{W}$ and $\mathrm{T}$ with the residual capacity measured at $28 \mathrm{~d}$ (group R), ageing effects were found in macro-synthetic FRC C1, smaller effects in C2, and no changes in C3 and C4. In the same way, no effects were observed in the steel FRC (C5) with the exception of the mentioned reduction in residual capacity observed in the group subjected to seawater treatment (group W).

\section{Acknowledgements}

The authors wish to thank the technicians of ICITECH, where the experimental work was developed. The financial support of the project FISNE with reference BIA2012-35776, supported by the Spanish Ministry of Economy and Competiveness and the FEDER fund, is also gratefully acknowledged. The doctoral scholarship of M. E. Bossio was supported by the project EuroTANGO (European Commission - EACEA).

\section{REFERENCES}

Arango S (2010) Flexural Creep of Steel Fibre Reinforced Concrete in Cracked State. Doctoral Thesis, Universitat Politècnica de València, Valencia, Spain (in Spanish).

Arango S, Serna P, Martí-Vargas JR and García-Taengua E (2012) Test method to characterize flexural creep behaviour of pre-cracked FRC specimens. Experimental Mechanics 52(8): 1067-1078.

Aslani F and Nejadi S (2013) Mechanical characteristics of self-compacting concrete with and without fibres. Magazine of Concrete Research 65(10): 608-622, http://dx.doi.org/10.1680/macr.12.00153.

ASTM (2007) C1609/C1609M-12: Standard test method for flexural performance of fiber-reinforced concrete (using beam with third-point loading). ASTM International, West Conshohoken, PA, USA.

ASTM (2008) D1141-98: Standard practice for the preparation of substitute ocean water. ASTM International, West Conshohoken, PA, USA.

Bernard ES (2010) Influence of fiber type on creep deformation of cracked fiber-reinforced shotcrete panels. ACI Materials Journal 107(5): 474-480. 


\section{Offprint provided courtesy of www.icevirtuallibrary.com Author copy for personal use, not for distribution}

BSI (2005) EN 14651:2005: Test method for metallic fibered concrete - Measuring the flexural tensile strength (limit of proportionality (LOP), residual). BSI, London, UK.

Buratti N and Mazzotti C (2012) Effects of different types and dosages of fibres on the long-term behaviour of fibre-reinforced self-compacting concrete. In RILEM PRO88, Proceedings of 8th RILEM International Symposium on Fibre Reinforced Concrete, Guimaraes, Portugal (Barros J (ed.)). RILEM Publications SARL, Bagneux, France, pp. 177-178.

de Montaignac R, Massicotte B and Charron JP (2013) Finite-element modelling of SFRC members in bending. Magazine of Concrete Research 65(19): 1133-1146, http:// dx.doi.org/10.1680/macr.11.00102.

FIB (Fédération Internationale du Béton) (2013) fib Model Code for Concrete Structures 2010. Ernst \& Sohn, Berlin, Germany.

Ganesan N, Santhakumar A and Indira PV (2014) Influence of steel fibres on tension stiffening and cracking of reinforced geopolymer concrete. Magazine of Concrete Research 66(6): 268-276, http://dx.doi.org/10.1680/macr.13.00273.

García-Taengua E, Arango S, Martí-Vargas JR and Serna P (2014) Flexural creep of steel fibre reinforced concrete in the cracked state. Construction and Building Materials $\mathbf{6 5}$ : 321-329.

Kanstad T and Žirgulis G (2012) Long-time creep testing of pre-cracked fibre reinforced concrete beams. In RILEM PRO88, Proceedings of 8th RILEM International Symposium on Fibre Reinforced Concrete, Guimaraes, Portugal (Barros J (ed.)). RILEM Publications SARL, Bagneux, France, pp. 195-196.
Mackay J and Trottier JF (2004) Shotcrete: more engineering developments. Proceedings of the Second International Conference on Engineering Developments in Shotcrete, October 2004, Cairns, Queensland, Australia (Bernard ES (ed.)), pp. 183-192.

Mazhar M, Abdouss M, Shariatinia Z and Zargaran M (2013) Grafting of continuous polypropylene fibres by methacrylic acid monomers to improve their bonding to concrete matrix. Magazine of Concrete Research 65(13): 802-808, http://dx.doi.org/10.1680/macr.13.00010.

Naghibdehi MG, Mastali M, Sharbatdar MK and Naghibdehi MG (2014) Flexural performance of functionally graded RC cross-section with steel and PP fibres. Magazine of Concrete Research 66(5): 219-233, http://dx.doi.org/ 10.1680/macr.13.00248.

Nakov D and Markovski G (2012) Time dependant behaviour of SFRC elements under sustained loads. In: RILEM PRO88, Proceedings of 8th RILEM International Symposium on Fibre Reinforced Concrete, Guimaraes, Portugal (Barros J (ed.)). RILEM Publications SARL, Bagneux, France, pp. 189-190.

Noushini A, Samali B and Vessalas K (2014) Static mechanical properties of polyvinyl alcohol fibre reinforced concrete (PVA-FRC). Magazine of Concrete Research 66(9): 465-483, http://dx.doi.org/10.1680/macr.13.00320.

Vasanelli E, Micelli F, Aiello MA and Plizzari G (2013) Long term behavior of FRC flexural beams under sustained load. Engineering Structures 56: 1858-1867.

Zerbino R and Barragán B (2012) Long-term behaviour of cracked steel fibre reinforced concrete beams under sustained loading. ACI Materials Journal 109(2): 215-224.

\section{WHAT DO YOU THINK?}

To discuss this paper, please submit up to 500 words to the editor at journals@ice.org.uk. Your contribution will be forwarded to the author(s) for a reply and, if considered appropriate by the editorial panel, will be published as a discussion in a future issue of the journal. 